\title{
Calotermes flavicollis.
}

I. Youngest larvae.

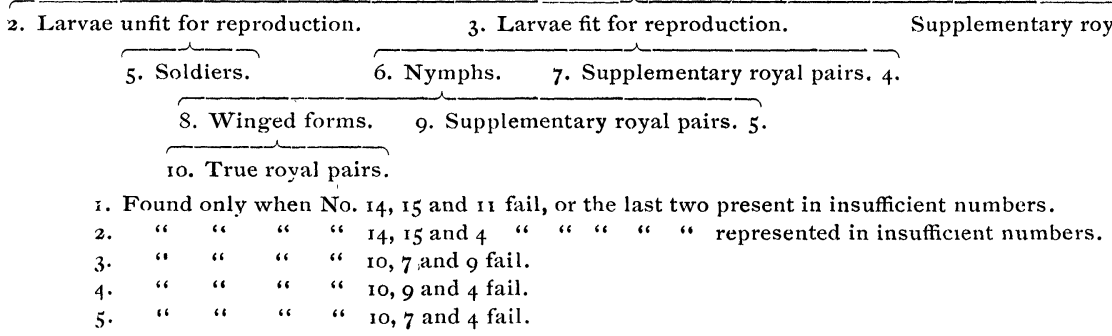

\section{NOTES ON ASILIDAE.}

BY S. W. WTLlistoN, NEW HAVEN, CONN.

In the preparation, some time ago, of a catalogue of the South American asilidae, and a partial study of a Brazilian collection, I made a number of notes, some of which seem of sufficient interest to publish. The catalogue includes no less than five hundred and forty names, not counting known synonyms, located under seventy-seven genera. The determination of species from among some of these is a dreary task, and in such gencra as Erax, with its seventy-six "species," or Mallopho$r a$, with fifty-six, almost impossible, save by the aid of large collections. Undoubtedly there are many synonyms among the names, yet enough must remain to demonstrate the richness of the South American fauna in this family.

In a comparison of the generic names I have found several preoccupied, for which I would propose the following:
For Laparus Loew, non Billberg, NeoLAPARUS ; for Cylindrophora Philippi, Lynchia, in honor of Enrique Lynch A.; for Phoneus Macquart, NeophoNErs; and, by the strict rights of priority, in which I fully believe, Neomoctherus O. S. must give place to Heligmoneura Bigot, and Andrenosoma Rondani to Nusa Walker.

It is very singular that Schiner, with his entomological acuteness should have so misunderstood the genus Senobasis Macquart, as he seems to have done. Macquart's characters were as follows: "Charactères génériques des Dasypogons. Troisième article des antennes à base très menues et extrémité fort renflée et ovale. Abdomen à base rétrécie; armature copulatrice ờ à pièces latérales en forme de crochets allongés. Cuisses nues. Ailes: quartrième cellule postérieure fermée, à nervure terminale arrondie." In his figures of $S$. analis 
he adds a short style to the antennae, of which he says nothing in the description, and which does not in reality exist. Now this peculiar structure of the antennae was what Schiner emphasized as the characteristic of Lochites. The narrowing of the base of the abdomen in Macquart's analis is slight, and but little more than occurs in some of Schiner's species. Not only are the genera the same, but I am not sure but that some of Macquart's and Schiner's species may be. Several species that I have examined convince me that the narrowing of the abdomen at the base is a very trivial character. Schiner referred to Senobasis the species of Blepharepium, with an elliptical third antennal joint, forms totally different. Bigot seems equally to have misunderstood the genus, which perhaps is not strange. Lochites must therefore be dropped, which is all the more necessary from the fact that the name was twice used before Schiner's. I leave to the purist the emendation of the name Senobasis.

The species from North America referred by me to Aphamartania Schiner, does not belong there, as true specimens of the genus prove; where it does belong I do not know.

In the collection are specimens of a Deromyia closely resembling $D$. misellus from North America, with the fourth posterior cell closed. Baron Osten Sacken (Biol. Centr. Amer. 173) refuses to accept the identity of Diogmites and Deromyia, or, accepting it, would place the latter as a synonym or subgenus of the former. I cannot agree with him. Philippi's description was as good as Loew's and a year earlier. I can see no reason whatever for rejecting Philippi's name, and, until further evidence from Philippi's type species is at hand, the name Diogmites should be dropped.

Schiner located the genus Pseudorus Walker under the dasypogoninae, and attributed to it three submarginal cells, expressly stating that he had examined two specimens. A specimen that I have examined, and which $I$ believe to be $P$. piceus Walker, has the marginal cell closed and with but two submarginal cells, agreeing in hoth respects with $P$. bicolor Bellardi. The genus is closely allied to Doryclus Jaenn.

Mr. Roeder has recently (Berl. ent. zeit. v. 21, 76) fully discussed the synonymy of Doryclus and Megapoda Macq., distinguishing them as gener:।, and clearing up the confusion of the species. Specimens of the two type species, Doryclus distendens (Wied.) Jaenn. and Megapoda labiata (Fabr.) Macq., convince me that he is quite right in separating the forms. Not only the characters of the legs, but the general habitus also, and the form of the face, are fully sufficient, in my opinion, to distinguish them. Pseudorus exists with less right than does Doryclus it seems to me. There is considerable variation in the three specimens I have examined, both male and female, of $D$. distendens, so that I am not prepared to say that the specific synonymy is correctly given by Roeder, but it 
seems extremely probable.

Both Lynch and Osten Sacken have commented upon the difficulty of identifying the described species of Atomosia, and I can agree with them. There seem to be numerous structural characters that have been but little used, either for generic or specific discrimination. As a contribution to the better definition of the Atomosia group of genera, I offer the following:

A.- Third joint of the antennae longer than the first two together. without style; eyes on the side of the front emarginate, the front not widened above; scutellum with bristles; first posterior: cell usually narrowed; body punctulate.

Atomosia Macq.

"Third antennal joint longer than the first two together, without distinct style [front?]; scutellum without bristles. Hind femora with spinous bristles; hind tibiae feebly ciliate within. Body punctulate."

Rhathimomyia Lynch.

"Third antennal joint longer than the first two together, without distinct style [Front broad above?]. Abdomen much constricted at base, not strongly punctulate ; wings and legs long."

Eumecosoma Schiner.

"Third antennal joint at least three times as long as the first two joints together, without style. Large species." [Front? punctulation?]

Aphestia Schiner.
Third joint of antennae longer than the first two together, with a terminal style; eyes not, or but very slightly emarginate on the sides of the front, the front much wider above; scutellum without bristles, or with hair-like ones. Atonia, gen. nov.

First joint of antennae about as long as the third, the latter without terminal style. Front much widened above, the eyes disciform and with enlarged facets in front; scutellum with weak bristles; body punctulate.

Cerotainia Schiner.

First joint of antennae as long as the third, without style. Scutellum without bristles. Abdomen punctulate, slender. Thorax remarkably projecting forward in a hemispherical, constricted eminence. Cyphotomyia, gen. nov. Third joint of the antennae longer than the first two together, without style; front wide above; scutellum with fine bristles ; seven abdominal segments visible in the male from above; abdomen smooth, not punctulate.

Lamprozona Loew.

The genus Atonia is. I believe, well founded, and will include a number of species, such as $A$. ancyloccra Schiner, A. mikii Williston, etc. Cyphotomyia is perhaps more doubtful, but the entire absence of bristles on the scutellum, and apparently also on the ocelligerous tubercle, together with the remarkable development of the thorax, will, I believe, justify its erection. The species 
upon which it is based I do not find anywhere described, and so give it here.

Cyphotomyia lynchii, sp. nov.

Antennae black, long (about as long as the hind femora) ; first joint about as long as the third, with hairs above, and a few bristles below; second joint short, with bristles ; third joint slender, pointed, without style, black pubescent. Face and front densely yellowish gray pubescent; face a little wider above, very slightly projecting below, with a few fine black bristles on the lower part. Front very deeply excavated, and very broad above, the inner margins of the eyes convex, the ocelligerous tubercle small and (in the single specimen) without bristles. Head nearly twice as wide as high, flat, the eyes disciform, and with distinctly enlarged facets in front. Proboscis not long, truncate, black. Thorax black, punctulate; mesonotum remarkably projecting above in front, forming a hemispherical protuberance, laterally constricted at its base. Abdomen black, slender, acuminate, strongly punctulate, the segments without lateral bristles. Femora black, tibiae and tarsi yellow, except that the tips of the four anterior tibiae, the distal part of the hind pair, and the last two or three joints of all the tarsi, are brown or blackish; tibiae and tarsi with slender yellow bristles; hind tibiae on the inner side with yellow pile as in most species of Cerotainia and Atomosia. Wings lightly infuscate (from the microscopic pubescence); petiole of marginal cell long; first and stcond posterior cells of nearly equal width distally, long; veins at outer end of the discal and fourth posterior cells nearly in the same straight line; small cross-vein before the middle of discal cell. Length $5 \mathrm{~mm}$.

One specimen, Chapada (near Cuyabá) Brazil, H. H. Smith.

Schiner long ago (Verh. zool.-bot. Gesellsch, 16,664) called attention to the artificial position of Atractia among the asilinae, sensu auctorum. I can only reiterate it, and protest against any classification that separates the genus from the immediate neighborhood of Atomosia, sensu strictiori. Indeed, as Schiner says, when the third antennal joint in any specimen is wanting, the species will be unhesitatingly referred to that genus. To separate Atractia, then, into another subfamily on the slight difference between a slender style (as in Atonia mikii Will.) and a short bristle, is absurd. Atractia, at present, includes but four species, three from South America, and one from Central America. 'Two additional species are represented in the Smith collection. Another species, of much larger size, and different appearance, also new, but more nearly related to some of the described species, has the abdomen entirely smooth, without punctulation, the proboscis longer, etc.; it may require the erection of a new genus for its reception. As in many of the species of the Atomosia group of genera, all these species have a minute projection on the upper border of the third antennal joint.

In the Ann. ent. soc. France, I 889, 
p. I 83 Bull., Bigot, in his characteristic way, proposes a new generic name, Pseudarchilestes, for Dasypogon albitarsis Macquart. The author could have hardly comprised more errors in one short note than he has done. First, Schiner first described the genus Archilestes (Archilestris) in the Verh. zool.bot. gesellsch. 1866, v. 16, p. 672, and not in Reise der österreichischen fregatte Novara, which appeared two years later. Second, he says nothing about D. magnificus Walker, being the same as $D$. albitarsis, but, on the contrary, places $D$. albitarsis as a synonym of D. capnopterus Wied.(op. cit., v. I6, p. 703 ; v. 17 , p. 377), the type of the genus. Had Bigot been at all familiar with what Schiner has written, he would have observed that Schiner says expressly (Verh. zool.-bot. gesellch. v. i7, p. 378 ) that the third antennal joint in A. capnopterus is "auf der Oberseite behaart," the very identical character that Bigot assumes as distinctive of his Pseudarchilestes! Furthermore, Schiner says nothing in his original generic description about the third joint not being hairy above. That he does say so in a later description was undoubtedly an oversight, that should not have been accepted so heedlessly. In a word, Bigot erects a new genus upon the type species of another genus, based upon a character that was expressly stated to be present in that type. Archilestris magnificus Walk. has, likewise, the "third joint of the antennae distinctly beset with hairs on the upper side." (Osten Sacken, Biol. Cent.Amer., p. 169.)

I wish to substitute Myiothera for Lynchia, p. 255, as I find the latter was used by Weyenbergh in $\mathrm{r} 88 \mathrm{r}$.

\section{NOTES ON THE EARLY STAGES OF SOME HETEROCERA.}

BY CAROLINE G. SOULE AND IDA M. ELIOT.

PANOPODA RUfimargo, VAR. ROSEIcosta, Guen.

This larva was .28 $\mathrm{mm}$. long, bright green, and found feeding on oak in Nonquitt, Mass., on ro September, I889.

The head was large, bright green, minutely speckled with black, and having a horizontal yellow line across the "forehead."

The body was bright, rich green, minutely speckled with black, and hav- ing subdorsal lines of bright yellow extending from the head to the end of the anal props.

On the first segment were four small yellow dots just behind the head, and two larger ones behind the four.

On the first and second segments were a faint yellow horizontal line, and three rough yellow tubercles.

There was a dorsal line of yellow dashes and the space on each side was 

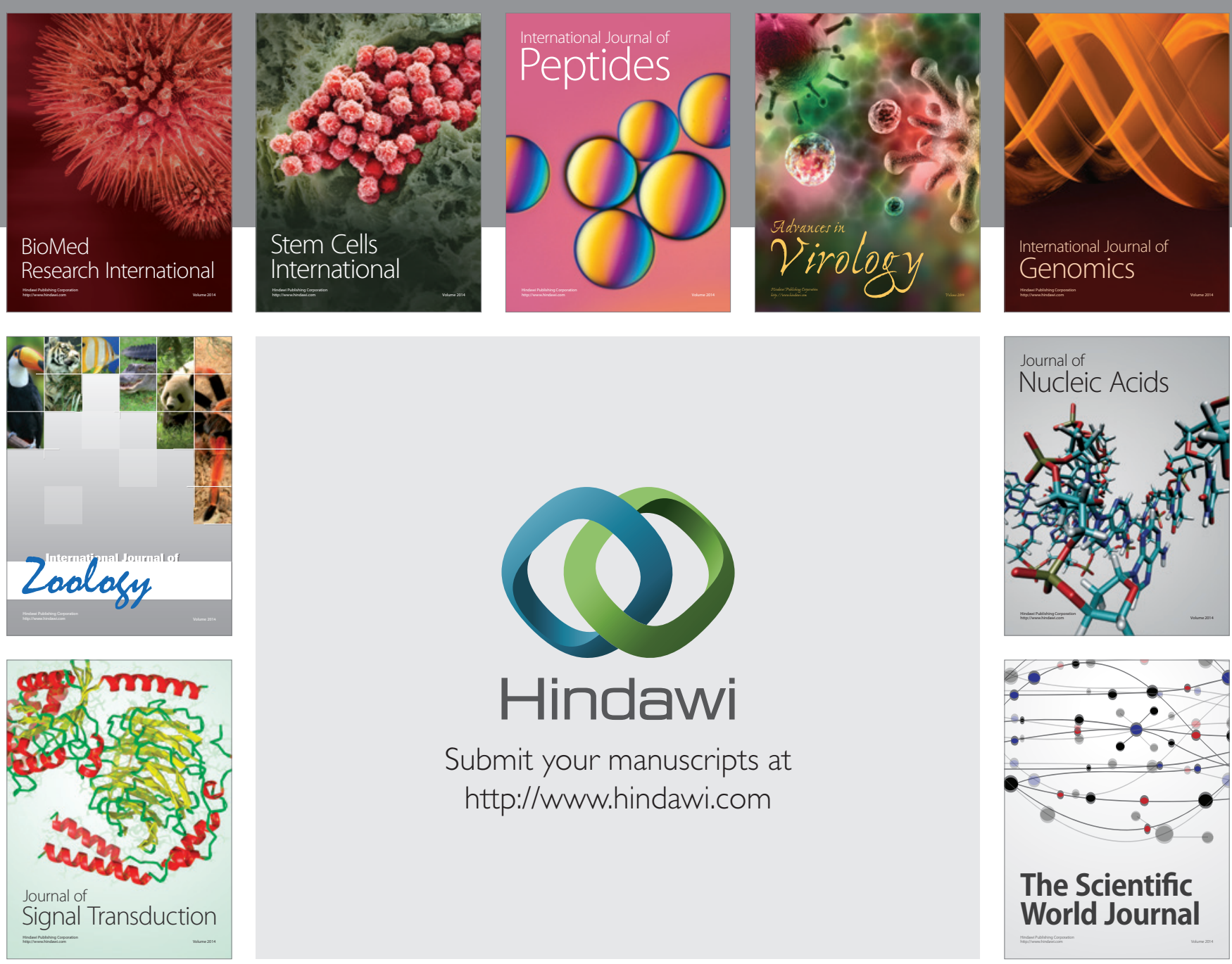

Submit your manuscripts at

http://www.hindawi.com
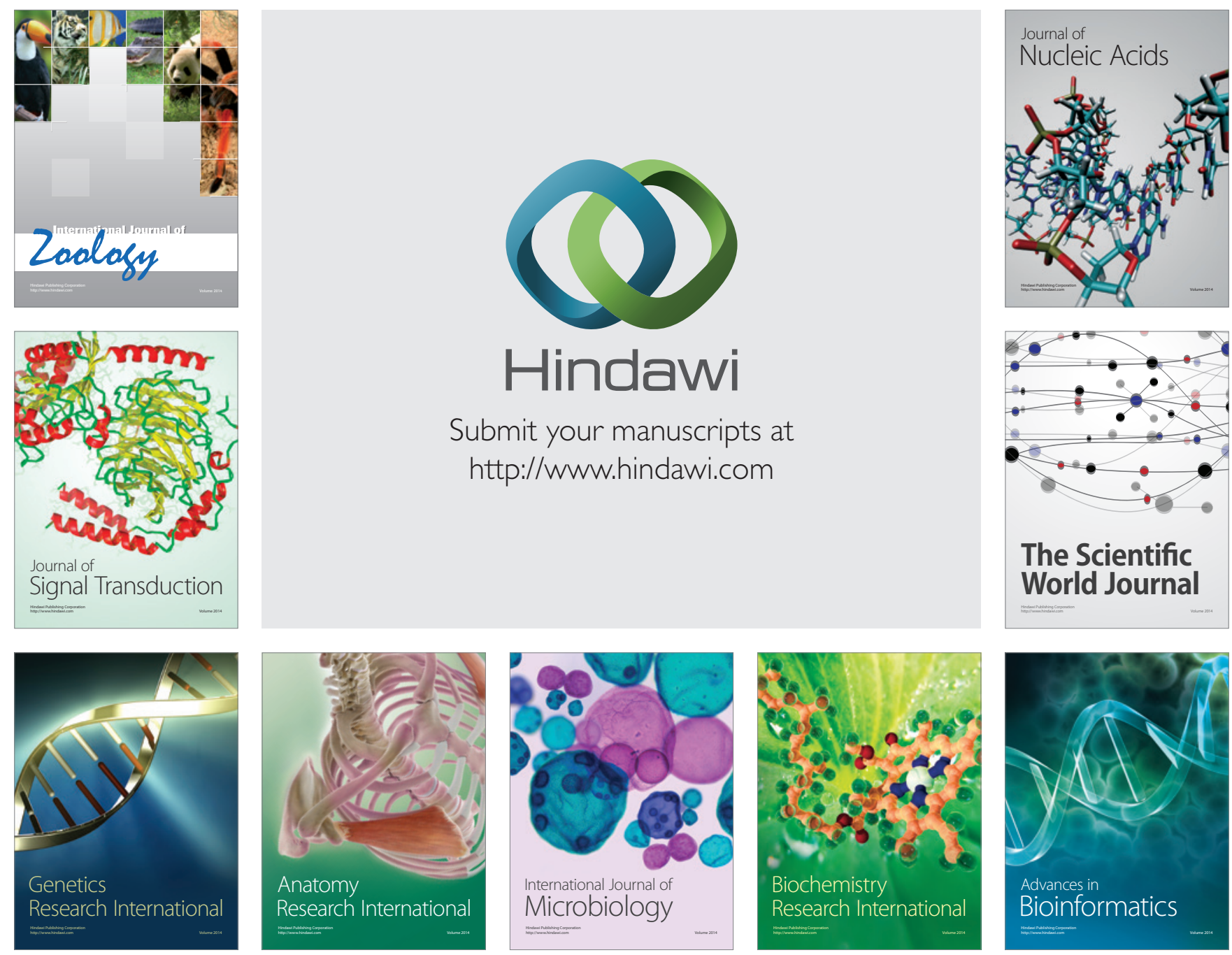

The Scientific World Journal
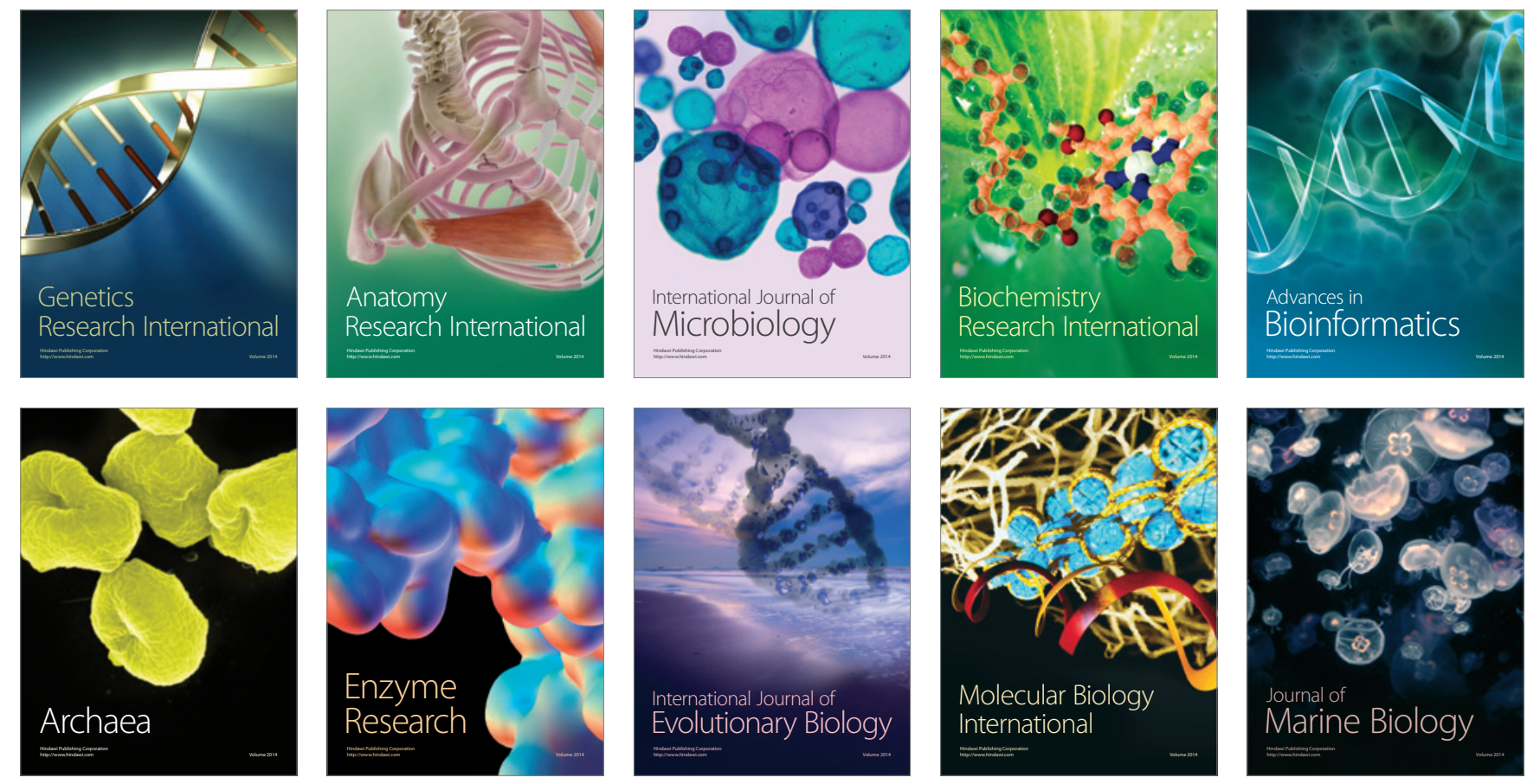